\title{
Penerapan Metode Moora Pada Sistem Pemilihan Mutu Jenis Klon Atau Bibit Tanaman Karet (Studi Kasus: Balai Penelitian Sembawa, Palembang)
}

\author{
Dea Vitara ${ }^{1}$, Widya Cholil*2 \\ 1,2Informatics Departement, Bina Darma University, Palembang, Indonesia \\ Email: deavitara19@gmail.com², widya@binadarma.ac.id²
}

\begin{abstract}
Rubber plants have a very important role for the Indonesian economy. Indonesia has a great opportunity to become a major rubber producer because it has very sufficient potential resources to increase production, both through expansion and replanting of plants with superior clones. South Sumatra Province is one of the largest rubber producers in Indonesia. Many farmers want to get the best rubber plants. The problem faced is how to choose the quality of the type of clone or the best rubber plant seeds. With a decision support system in analyzing the quality data of clone types or rubber plant seeds, one of them is by applying the MOORA (Multi-Objective Optimization by Ratio Analysis) method which is expected to produce the best prediction of the quality rank of clones. MOORA calculation method will be implemented in a web using MySQL.
\end{abstract}

Keywords: Decision Support Systems, Rubber Plants, Types of Clones, MOORA Method, MySQL.

\section{PENDAHULUAN}

Pada pemilihan bibit karet, petani masih sulit menentukan jenis karet mana yang baik. Karena banyaknya jenis klon tanaman karet yang ada, namun belum diprediksi mutu pada jenis klon mana yang paling baik digunakan para petani karet. Dalam perkembangan ilmu pengetahuan dan teknologi saat ini yang semakin pesat dalam berbagai bidang, tidak terkecuali dalam bidang teknologi informasi yang dapat dimanfaatkan secara optimal. Teknologi informasi juga dapat dimanfaatkan sebagai pendukung dalam memberikan solusi terhadap masalah.

Sistem pendukung keputusan termasuk cabang ilmu komputer berbasis Artificial intelligence atau biasa juga disebut dengan kecerdasan buatan yang 


\section{Journal of Software Engineering Ampera}

Vol. 2, No. 1, February 2021 e-ISSN: xxxx-xxxx

https://journal-computing.org/index.php/journal-sea/index

biasanya digunakan suatu permasalahan bersifat komplek. Dari penjelasan tersebut, peneliti membangun sistem pendukung keputusan guna memberikan solusi yang terjadi pada permasalahan diatas menggunakan sistem perankingan. Untuk metode yang dipilh yaitu metode MOORA.

Dengan metode MOORA dapat memberikan perankingan data agar lebih mudah menentukan mutu jenis klon atau bibit tanaman karet yang terbaik. Sistem perhitungan akan diimplementasikan pada Web menggunakan MySQL. Diharapkan dari penelitian ini dapat memberikan sebuah cara pemilihan yang ideal kepada Riset perkebunan Balai penelitian Sembawa dalam memilih mutu tanaman karet yang terbaik untuk para petani karet.

\section{METODOLOGI PENELITIAN}

\subsection{Metode Penelitian}

Dalam melakukan penelitian penulis menggunakan metode MOORA dalam perhitungan untuk mendapatkan perangkingan pada data menentukan pemilihan mutu tanaman karet berdasarkan jenis klon. Dan diimplementasikan pada web menggunakan MySQL. Dibawah ini merupakan langkah penyelesaian dari metode MOORA sebagai berikut:

1. Menginput atau memasukan nilai kriteria, Memilih tujuan dalam mengidentifikasi atribut evaluasi yang berkaitan dan menginputkan nilai kriteria dari suatu alternatif, nilai tersebut nantinya diolah kemudian hasilnya akan menjadi sebuah keputusan.

2. Membuat sebuah matriks keputusan

$$
\mathrm{X}=\left[\begin{array}{ccc}
x_{11} & x_{1 i} & x_{1 n} \\
x_{j 1} & x_{i j} & x_{j n} \\
x_{m 1} & x_{m i} & x_{m n}
\end{array}\right]
$$

\section{Keterangan}

- $\mathrm{x}_{\mathrm{ij}} \quad$ : Respon alternatif $\mathrm{j}$ dalam kriteria i

- i $\quad: 1,2,3, \ldots, n$ merupakan nomor urutan atribut atau kriteria

- $\mathrm{j} \quad: 1,2,3, \ldots, \mathrm{m}$ merupakan nomor urutan alternatif

- $\mathrm{X}$ : Untuk matriks Keputusan

3. Melakukan normalisasi dalam metode MOORA, Normalisasi menggabungkan setiap element matriks sehingga element yang 


\section{Journal of Software Engineering Ampera}

Vol. 2, No. 1, February 2021 e-ISSN: xxxx-xxxx

https://journal-computing.org/index.php/journal-sea/index

terdapat pada matriks memiliki nilai yang serupa. Dalam metode MOORA, normalisasibiasanya dihitung menggunakan persamaan berikut :

$$
x^{*} i j=\frac{x_{i j}}{\sqrt{\sum_{i=1}^{m} x_{i j}^{2}}}
$$

\section{Keterangan}

- $\mathrm{x}_{\mathrm{ij}} \quad$ : Matriks alternatif $\mathrm{j}$ dalam kriteria i

- i $\quad: 1,2,3, \ldots, n$ merupakan nomor urutan atribut atau kriteria

- $\mathrm{j} \quad: 1,2,3, \ldots, \mathrm{m}$ merupakan nomor urutan alternatif

- $\mathrm{X}_{\mathrm{ij}}^{*} \quad$ : Matriks Normalisasi alternatif $\mathrm{j}$ dalam kriteria $\mathrm{i}$

4. Optimalkan Atribut, dalam optimasi atribut, normalisasi ini ditambahkan untuk menguntungkan atribut yaitu dapat dikatakan benefit, dan untuk atribut yang tidak menguntungkan yaitu bisa dikataka cost. Maka masalah optimasi menjadi:

$$
y^{*} j=\sum_{i=1}^{i=g} x_{i j}^{*}-\sum_{i=g+1}^{i=n} x_{i j}^{*}
$$

\section{Keterangan}

- i $\quad: 1,2,3, \ldots$, g merupakannilai kriteria dengan status maximized

- j : $\mathrm{j}+1, \mathrm{~g}+2, \mathrm{~g}+3, \ldots, \mathrm{n}$ merupakan nilai kriteria dengan status minimized

- $y_{j}^{*} \quad$ : Merupakan matriks Normalisasi max-min pada alternatif $j$

5. Meminimalisasikan nilai maximax dan minmax menandakan bahwa suatu atribut lebih berguna biasanya dikalikan dengan bobot yang sesuai dengan nilai benefit dan cost. Setiap atribut bobot dalam perhitungannya telah dipertimbangkanmenggunakan perhitungan berikut .

$$
y_{i}=\sum_{j=1}^{g} w_{j} x_{i j}^{*}-\sum_{j=g+1}^{n} w_{j} x_{i j}^{*}
$$

Keterangan 


\section{Journal of Software Engineering Ampera}

Vol. 2, No. 1, February 2021 e-ISSN: xxxx-xxxx

https://journal-computing.org/index.php/journal-sea/index

- i $\quad: 1,2,3, \ldots$, g merupakan kriteria dengan status maximized

- $\mathrm{j} \quad \mathrm{g} \mathrm{g}+1, \mathrm{~g}+2, \mathrm{~g}+3, \ldots, \mathrm{n}$ merupakan kriteria dengan status minimized

- $w_{j} \quad$ : bobot pada alternatif $j$

- $y_{j}^{*} \quad$ : Nilai yang telah dinormalisasi dari alternatif $j$ terhadap semua atribut.

6. Menentukan ranking dari hasil perhitungan MOORA.

KeluaranPada Perhitungan Metode MOORA, (a) Alternatif terbaik memiliki nilai akhir $\left(\mathrm{y}_{\mathrm{i}}\right)$ yang tertinggi, alternatif ini digunakan sesuai permasalahan yang ada karena ini adalah pilihan terbaik. (b) Sedangkan alternatif yang terburuk memiliki nilai akhir $\left(\mathrm{y}_{\mathrm{i}}\right)$ terendah dari data yang ada.

\section{HASIL DAN PEMBAHASAN}

\subsection{Hasil Perhitungan}

1. Analisa Kriteria

Langkah awal dari penyelesaian ini adalah menganalisis kriteria yang dilakukannya proses pertama seleksi. Adapun kriteria yang digunakan adalah KKK (C1), Po (C2), PRI (C3), Vr (C4), Luv (C5). Contoh data dari kriteria tersebut adalah :

Tabel 1. Data Kriteria

\begin{tabular}{cccc}
\hline Kriteria & Keterangan & Bobot & Jenis \\
\hline C1 & KKK & $25 \%$ & Benefit \\
C2 & Po & $10 \%$ & Cost \\
C3 & PRI & $20 \%$ & Benefit \\
C4 & Vr & $25 \%$ & Benefit \\
C5 & Luv & $20 \%$ & Benefit \\
\hline
\end{tabular}

Tabel 2. Data Rating Kecocokan

\begin{tabular}{cccccc}
\hline \multirow{2}{*}{ KLON } & \multicolumn{5}{c}{ PARAMETER MUTU SIR } \\
\cline { 2 - 6 } & KKK & PO & PRI & Vr & LUV \\
\hline BPM 24 & R & S & T & T & S \\
BPM 107 & R & R & S & S & S \\
BPM 109 & S & S & S & ST & S \\
\hline
\end{tabular}




\section{Journal of Software Engineering Ampera}

Vol. 2, No. 1, February 2021 e-ISSN: xxxx-xxxx

https://journal-computing.org/index.php/journal-sea/index

\begin{tabular}{cccccc}
\hline & & & & & \\
\hline BPM 104 & $\mathrm{T}$ & $\mathrm{S}$ & $\mathrm{R}$ & $\mathrm{T}$ & $\mathrm{S}$ \\
PB 260 & $\mathrm{R}$ & $\mathrm{R}$ & $\mathrm{S}$ & $\mathrm{S}$ & $\mathrm{S}$ \\
BPM 1 & $\mathrm{S}$ & $\mathrm{S}$ & $\mathrm{S}$ & $\mathrm{T}$ & $\mathrm{T}$ \\
AVROS & $\mathrm{T}$ & $\mathrm{ST}$ & $\mathrm{S}$ & $\mathrm{ST}$ & $\mathrm{T}$ \\
2037 & & & & & \\
PB 330 & - & - & - & - & - \\
RRIC 100 & $\mathrm{T}$ & $\mathrm{S}$ & $\mathrm{S}$ & $\mathrm{T}$ & $\mathrm{S}$ \\
IRR 5 & $\mathrm{T}$ & $\mathrm{S}$ & $\mathrm{T}$ & $\mathrm{T}$ & $\mathrm{T}$ \\
IRR 39 & $\mathrm{S}$ & $\mathrm{T}$ & $\mathrm{R}$ & $\mathrm{ST}$ & $\mathrm{S}$ \\
IRR 42 & $\mathrm{S}$ & $\mathrm{T}$ & $\mathrm{R}$ & $\mathrm{ST}$ & $\mathrm{T}$ \\
IRR 118 & $\mathrm{T}$ & $\mathrm{S}$ & $\mathrm{S}$ & $\mathrm{S}$ & $\mathrm{T}$ \\
IRR 220 & $\mathrm{S}$ & $\mathrm{R}$ & $\mathrm{R}$ & $\mathrm{S}$ & - \\
\hline
\end{tabular}

\section{Pembobotan Kriteria}

Dalam menentukan pemilihan jenis klon atau bibit tanaman karet terbaik menggunakan metode MOORA, maka terlebih dahulu ditentukan nilai awal dari setiap kriteria, pada penilaian bilangan fuzzy terdiri dari, SR (Sangat Rendah), R(Rendah), S (Sedang), T (Tinggi), ST (Sangat Tinggi), yangdapat dilihat pada Gambar 1.

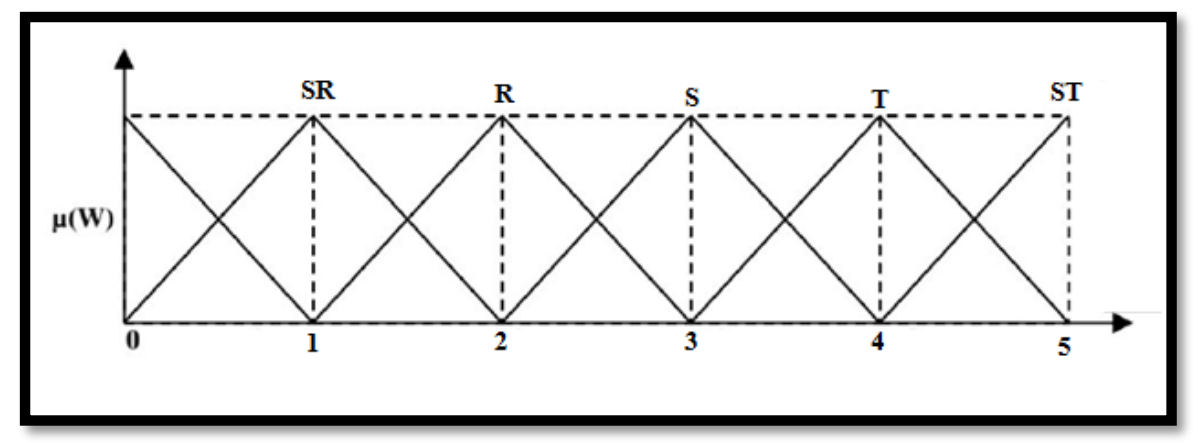

Gambar 1 DiagramFuzzy untuk nilai kriteria

Pada gambar diatas, bilangan fuzzy dikonversikan ke bilangan crisp. Untuk lebih jelasnya data bilangan fuzzybisa dilihat dalam tabel dibawah ini. 


\section{Journal of Software Engineering Ampera}

Vol. 2, No. 1, February 2021 e-ISSN: xxxx-xxxx

https://journal-computing.org/index.php/journal-sea/index

Tabel 3 Pembobotan Kriteria

\begin{tabular}{cc}
\hline Bobot & Nilai \\
\hline - & 0 \\
Sangat Rendah (SR) & 1 \\
Rendah (R) & 2 \\
Sedang (S) & 3 \\
Tinggi (T) & 4 \\
Sangat Tinggi (ST) & 5 \\
\hline
\end{tabular}

Setelah dilakukan pembobotan kriteria, kemudian dapat dilihat kecocokan data pada setiap alternatif terhadap kriteria yang dapat dilihat dalam tabel berikut.

Tabel 4 Rating Kecocokan

\begin{tabular}{ccccccc}
\hline \multirow{2}{*}{ No } & Alternatif & \multicolumn{5}{c}{ Kriteria } \\
\cline { 3 - 7 } & & KKK & Po & PRI & Vr & LuV \\
\hline 1 & BPM 24 & 2 & 3 & 4 & 4 & 3 \\
2 & BPM 107 & 2 & 2 & 3 & 3 & 3 \\
3 & BPM 109 & 3 & 3 & 3 & 5 & 3 \\
4 & BPM 104 & 4 & 3 & 2 & 4 & 3 \\
5 & PB 260 & 2 & 2 & 3 & 3 & 3 \\
6 & BPM 1 & 3 & 3 & 3 & 4 & 4 \\
7 & AVROS 2037 & 4 & 5 & 3 & 5 & 4 \\
8 & PB 330 & 0 & 0 & 0 & 0 & 0 \\
9 & RRIC 100 & 4 & 3 & 3 & 4 & 3 \\
10 & IRR 5 & 4 & 3 & 4 & 4 & 4 \\
11 & IRR 39 & 3 & 4 & 2 & 5 & 3 \\
12 & IRR 42 & 3 & 4 & 2 & 5 & 4 \\
13 & IRR 118 & 4 & 3 & 3 & 3 & 4 \\
14 & IRR 220 & 3 & 2 & 2 & 3 & 0 \\
\hline
\end{tabular}

Dibawah ini adalah langkah penyelesaian pada metode MOORA :

a. Matriks $X_{i j}$ 


\section{Journal of Software Engineering Ampera}

Vol. 2, No. 1, February 2021 e-ISSN: xxxx-xxxx

https://journal-computing.org/index.php/journal-sea/index

$X_{i j}=\left(\begin{array}{lllll}2 & 3 & 4 & 4 & 3 \\ 2 & 2 & 3 & 3 & 3 \\ 3 & 3 & 3 & 5 & 3 \\ 4 & 3 & 2 & 4 & 3 \\ 2 & 2 & 3 & 3 & 3 \\ 3 & 3 & 3 & 4 & 4 \\ 4 & 5 & 3 & 5 & 4 \\ 0 & 0 & 0 & 0 & 0 \\ 4 & 3 & 3 & 4 & 3 \\ 4 & 3 & 4 & 4 & 4 \\ 3 & 4 & 2 & 5 & 3 \\ 3 & 4 & 2 & 5 & 4 \\ 4 & 3 & 3 & 3 & 4 \\ 3 & 2 & 2 & 3 & 0\end{array}\right)$

b. Matriks Kinerja ternormalisasi Kriteria 1 KKK (C1)

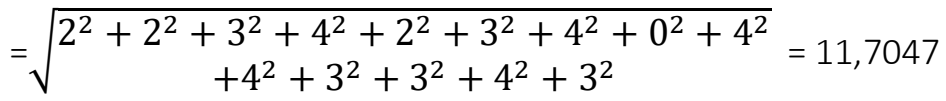

$A_{11}=2 / 11,7047=0,1709$

$A_{21}=2 / 11,7047=0,1709$

$A_{31}=3 / 11,7047=0,2563$

$A_{41}=4 / 11,7047=0,3417$

$A_{51}=2 / 11,7047=0,1709$

$A_{61}=3 / 11,7047=0,2563$

$A_{71}=4 / 11,7047=0,3417$

$A_{81}=0$

$A_{91}=4 / 11,7047=0,3417$

$A_{101}=4 / 11,7047=0,3417$

$A_{111}=3 / 11,7047=0,2563$

$A_{121}=3 / 11,7047=0,2563$

$A_{131}=4 / 11,7047=0,3417$

$A_{141}=3 / 11,7047=0,2563$

Kriteria 2 Po (C2)

$$
\begin{aligned}
& =\sqrt{\begin{array}{c}
3^{2}+2^{2}+3^{2}+3^{2}+2^{2}+3^{2}+5^{2}+0^{2}+3^{2} \\
+3^{2}+4^{2}+4^{2}+3^{2}+2^{2}
\end{array}=11,4891} \\
& A_{12}=3 / 11,4891=0,2611 \\
& A_{22}=2 / 11,4891=0,1741
\end{aligned}
$$




\section{Journal of Software Engineering Ampera}

Vol. 2, No. 1, February 2021 e-ISSN: xxxx-xxxx

https://journal-computing.org/index.php/journal-sea/index

$$
\begin{aligned}
& A_{32}=3 / 11,4891=0,2611 \\
& A_{42}=3 / 11,4891=0,2611 \\
& A_{52}=2 / 11,4891=0,1741 \\
& A_{62}=3 / 11,4891=0,2611 \\
& A_{72}=5 / 11,4891=0,4352 \\
& A_{82}=0 \\
& A_{92}=3 / 11,4891=0,2611 \\
& A_{102}=3 / 11,4891=0,2611 \\
& A_{112}=4 / 11,4891=0,3482 \\
& A_{122}=4 / 11,4891=0,3482 \\
& A_{132}=3 / 11,4891=0,2611 \\
& A_{142}=2 / 11,4891=0,1741
\end{aligned}
$$

Kriteria 3 PRI (C3)

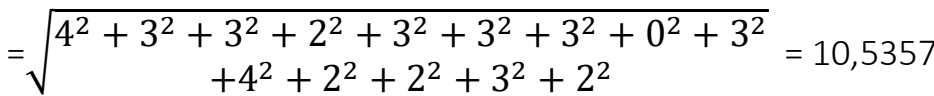

$$
\begin{aligned}
& A_{13}=4 / 10,5357=0,3797 \\
& A_{23}=3 / 10,5357=0,2847 \\
& A_{33}=3 / 10,5357=0,2847 \\
& A_{43}=2 / 10,5357=0,1898 \\
& A_{53}=3 / 10,5357=0,2847 \\
& A_{63}=3 / 10,5357=0,2847 \\
& A_{73}=3 / 10,5357=0,2847 \\
& A_{83}=0 \\
& A_{93}=3 / 10,5357=0,2847 \\
& A_{103}=4 / 10,5357=0,3797 \\
& A_{113}=2 / 10,5357=0,1898 \\
& A_{123}=2 / 10,5357=0,1898 \\
& A_{133}=3 / 10,5357=0,2847 \\
& A_{143}=2 / 10,5357=0,1898
\end{aligned}
$$

Kriteria $4 \mathrm{Vr}(\mathrm{C} 4)$

$$
\begin{aligned}
& =\sqrt{\begin{array}{c}
4^{2}+3^{2}+5^{2}+4^{2}+3^{2}+4^{2}+5^{2}+0^{2}+4^{2} \\
+4^{2}+5^{2}+5^{2}+3^{2}+3^{2}
\end{array}=14,6969} \\
& A_{14}=4 / 14,6969=0,2722
\end{aligned}
$$




\section{Journal of Software Engineering Ampera}

Vol. 2, No. 1, February 2021 e-ISSN: xxxx-xxxx

https://journal-computing.org/index.php/journal-sea/index

$$
\begin{aligned}
& A_{24}=3 / 14,6969=0,2041 \\
& A_{34}=5 / 14,6969=0,3402 \\
& A_{44}=4 / 14,6969=0,2722 \\
& A_{54}=3 / 14,6969=0,2041 \\
& A_{64}=4 / 14,6969=0,2722 \\
& A_{74}=5 / 14,6969=0,3402 \\
& A_{84}=0 \\
& A_{94}=4 / 14,6969=0,2722 \\
& A_{104}=4 / 14,6969=0,2722 \\
& A_{114}=5 / 14,6969=0,3402 \\
& A_{124}=5 / 14,6969=0,3402 \\
& A_{134}=3 / 14,6969=0,2041 \\
& A_{144}=3 / 14,6969=0,2041 \\
& \text { Kriteria } 5 \text { Luv }(C 5) \\
& =\sqrt{3^{2}}+3^{2}+3^{2}+3^{2}+3^{2}+4^{2}+4^{2}+0^{2}+3^{2} \\
& A_{15}=3 / 11,9583=0,2509 \\
& A_{25}=3 / 11,9583=0,2509 \\
& A_{35}=3 / 11,9583=0,2509 \\
& A_{45}=3 / 11,9583=0,2509 \\
& A_{55}=3 / 11,9583=0,2509 \\
& A_{65}=4 / 11,9583=0,3345 \\
& A_{75}=4 / 11,9583=0,3345 \\
& A_{85}=0 \\
& A_{95}=3 / 11,9583=0,2509 \\
& A_{105}=4 / 11,9583=0,3345 \\
& A_{125}=4 / 11,9583=0,3345 \\
& A_{135}=4 / 11,9583=0,3345 \\
& A_{145}=0 \\
&
\end{aligned}
$$

Pada haasil perhitungan di atas, berikut merupakan matriks kinerja yang ternormalisasi : 


\section{Journal of Software Engineering Ampera}

Vol. 2, No. 1, February 2021 e-ISSN: xxxx-xxxx

https://journal-computing.org/index.php/journal-sea/index

$X_{i j}=\left(\begin{array}{ccccc}0,1709 & 0,2611 & 0,3797 & 0,2722 & 0,2509 \\ 0,1709 & 0,1741 & 0,2847 & 0,2041 & 0,2509 \\ 0,2563 & 0,2611 & 0,2847 & 0,3402 & 0,2509 \\ 0,3417 & 0,2611 & 0,1898 & 0,2722 & 0,2509 \\ 0,1709 & 0,1741 & 0,2847 & 0,2041 & 0,2509 \\ 0,2563 & 0,2611 & 0,2847 & 0,2722 & 0,3345 \\ 0,3417 & 0,4352 & 0,2847 & 0,3402 & 0,3345 \\ 0 & 0 & 0 & 0 & 0 \\ 0,3417 & 0,2611 & 0,2847 & 0,2722 & 0,2509 \\ 0,3417 & 0,2611 & 0,3797 & 0,2722 & 0,3345 \\ 0,2563 & 0,3482 & 0,1898 & 0,3402 & 0,2509 \\ 0,2563 & 0,3482 & 0,1898 & 0,3402 & 0,3345 \\ 0,3417 & 0,2611 & 0,2847 & 0,2041 & 0,3345 \\ 0,2563 & 0,1741 & 0,1898 & 0,2041 & 0 \\ & & & & \end{array}\right)$

Pencarian y ternormalisasi disertakan dengan perkalian bobot. Maka didapat nilai $X_{i j} * W_{j}$ sebagai berikut:

$\begin{array}{ccccc}0,0427 & 0,0261 & 0,0759 & 0,0681 & 0,0502 \\ 0,0427 & 0,0174 & 0,0569 & 0,0510 & 0,0502 \\ 0,0641 & 0,0261 & 0,0569 & 0,0851 & 0,0502 \\ 0,0854 & 0,0261 & 0,0379 & 0,0681 & 0,0502 \\ 0,0427 & 0,0174 & 0,0569 & 0,0510 & 0,0502 \\ 0,0641 & 0,0261 & 0,0569 & 0,0681 & 0,0669 \\ 0,0854 & 0,0435 & 0,0569 & 0,0851 & 0,0669 \\ 0 & 0 & 0 & 0 & 0 \\ 0,0854 & 0,0261 & 0,0569 & 0,0681 & 0,0502 \\ 0,0854 & 0,0261 & 0,0759 & 0,0681 & 0,0669 \\ 0,0641 & 0,0348 & 0,0379 & 0,0851 & 0,0502 \\ 0,0641 & 0,0348 & 0,0379 & 0,0851 & 0,0669 \\ 0,0854 & 0,0261 & 0,0569 & 0,0510 & 0,0669 \\ 0,0641 & 0,0174 & 0,0379 & 0,0510 & 0 \\ & & & & \end{array}$

Setelah dilakukannya perkalian antara nilai $X_{i j}$ dan $W_{j}$ maka selanjutnya dilakukan perhitungan pada nilai Yi yang dapat dilihat pada tabel berikut.

Tabel 5 Nilai Yi dalam Metode MOORA

\begin{tabular}{cccc}
\hline Alternatif & Max & Min & Yi (Max-Min) \\
\hline BPM 24 & 0,2369 & 0,0261 & 0,2108 \\
\hline
\end{tabular}




\section{Journal of Software Engineering Ampera}

Vol. 2, No. 1, February 2021 e-ISSN: xxxx-xxxx

https://journal-computing.org/index.php/journal-sea/index

\begin{tabular}{cccc}
\hline BPM 107 & 0,2008 & 0,0174 & 0,1834 \\
BPM 109 & 0,2563 & 0,0261 & 0,2302 \\
BPM 104 & 0,2416 & 0,0261 & 0,2155 \\
PB 260 & 0,2008 & 0,0174 & 0,1834 \\
BPM 1 & 0,256 & 0,0261 & 0,2299 \\
AVROS 2037 & 0,2943 & 0,0435 & 0,2508 \\
PB 330 & 0 & 0 & 0 \\
RRIC 100 & 0,2606 & 0,0261 & 0,2345 \\
IRR 5 & 0,2963 & 0,0261 & 0,2702 \\
IRR 39 & 0,2373 & 0,0348 & 0,2025 \\
IRR 42 & 0,254 & 0,0348 & 0,2192 \\
IRR 118 & 0,2602 & 0,0261 & 0,2341 \\
IRR 220 & 0,153 & 0,0174 & 0,1356 \\
\hline
\end{tabular}

Tabel 6 Perangkingan pada nilai Alternatif

\begin{tabular}{ccc}
\hline Alternatif & Yi (Max) & Rangking \\
\hline BPM 24 & 0,2108 & 9 \\
BPM 107 & 0,1834 & 11 \\
BPM 109 & 0,2302 & 5 \\
BPM 104 & 0,2155 & 8 \\
PB 260 & 0,1834 & 11 \\
BPM 1 & 0,2299 & 6 \\
AVROS 2037 & 0,2508 & 2 \\
PB 330 & 0 & 14 \\
RRIC 100 & 0,2345 & 3 \\
IRR 5 & 0,2702 & 1 \\
IRR 39 & 0,2025 & 10 \\
IRR 42 & 0,2192 & 7 \\
IRR 118 & 0,2341 & 4 \\
IRR 220 & 0,1356 & 13 \\
\hline
\end{tabular}

Pada tabel 6, maka dapat disimpulkan bahwa mutu tanaman karet terbaik berdasarkan jenis klon yang bernilai nilai Yi (Max) tertinggi adalah jenis klon IRR 5 dengan nilai = 0,2702. 


\section{Journal of Software Engineering Ampera}

Vol. 2, No. 1, February 2021 e-ISSN: xxxx-xxxx

https://journal-computing.org/index.php/journal-sea/index

\subsection{Implementasi}

Berikut hasil uji coba pada yang dilakukan pada web dan tampilan dari setiap menu yang ada pada sistem pemilihan jenis klon tanaman karet menggunakan metode MOORA.

\subsubsection{Halaman Utama}

Pada halaman ini bisa diakses oleh siapa saja, karena ini bersifat umum. User dapat melakukan proses lihat menu dashboard, data jenis klon terbaik, dan menu login untuk admin.

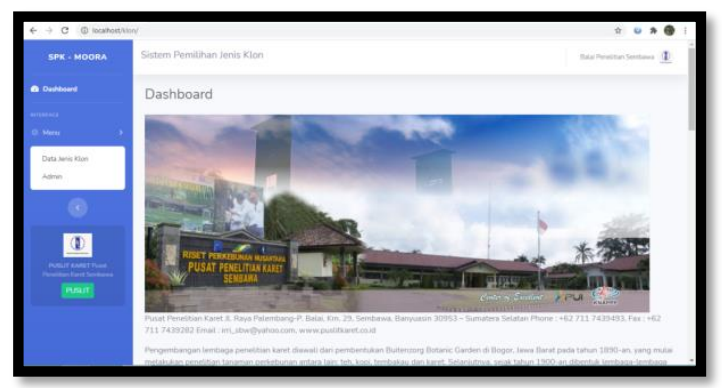

Gambar 2 Halaman Utama

\subsubsection{Halaman Data Jenis Klon}

Pada halaman ini memberikan informasi data jenis klon atau bibit tanaman karet terbaik berdasarkan peringkatnya, data ini didapatkan otomatis pada proses perhitungan data pada admin.

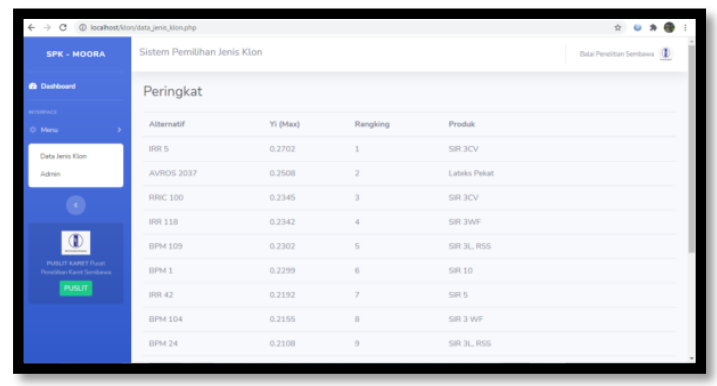

Gambar 3 Data Jenis Klon

\subsubsection{Halaman Login Admin}

Halaman ini berfungsi sebagai tempat admin login di halaman admin, pada halaman admin, terdapat menu yang akan mengelolah data untuk sistem penentuan jenis klon berdasarkan peringkat menggunakan metode MOORA. 


\section{Journal of Software Engineering Ampera}

Vol. 2, No. 1, February 2021 e-ISSN: xxxx-xxxx

\section{https://journal-computing.org/index.php/journal-sea/index}

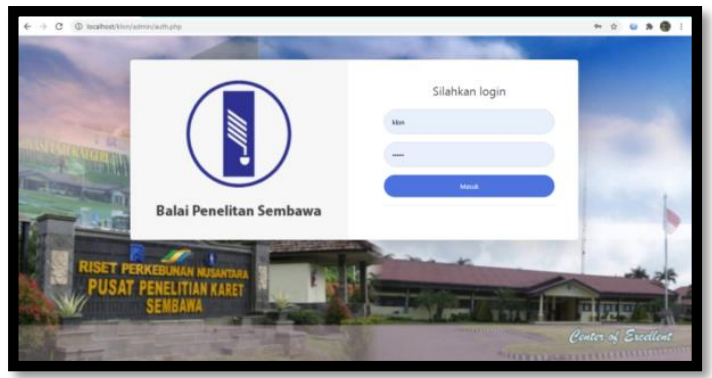

Gambar 4 Halaman Login Admin

\subsubsection{Halaman Data}

Pada halaman ini menampilkan proses untuk menambahkan atau mengedit isi data jenis klon. jika data ini diubah maka perubahan juga terjadi pada data pada saat di menu perhitungan MOORA.

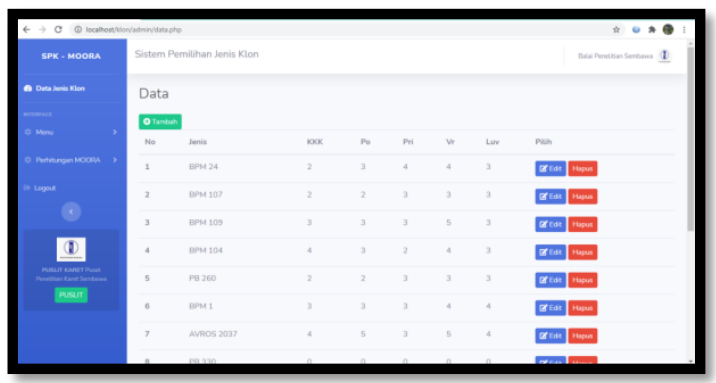

Gambar 5 Halaman Data

\subsubsection{Halaman Tambah Data}

Halaman ini untuk menambah atau menginput data baru.

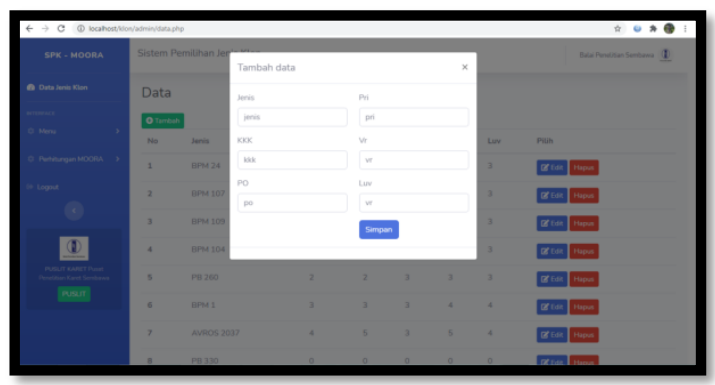

Gambar 6 Halaman Tampilan Tambah Data 


\section{Journal of Software Engineering Ampera}

Vol. 2, No. 1, February 2021 e-ISSN: xxxx-xxxx

https://journal-computing.org/index.php/journal-sea/index

\subsubsection{Halaman Produk}

Halaman ini merupakan halaman untuk menginput dan mengedit data produk berdasarkan masing-masing jenis klon. Nantinya data ini secara otomatis akan masuk ke halaman utama user pada menu data jenis klon.

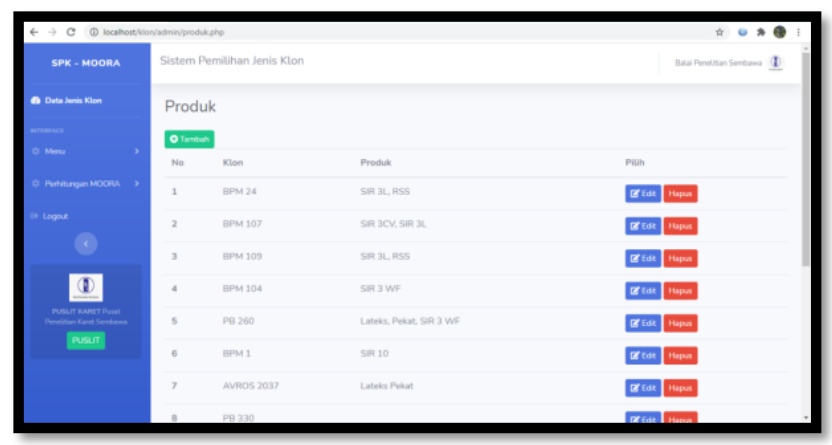

Gambar 7 Tampilan Halaman Produk

\subsubsection{Halaman Bobot Parameter}

Tampilan pada halaman ini digunakan untuk mengelolah data bobot parameter dan menginputkan isi dari data. Data ini digunakan untuk perhitungan MOORA.

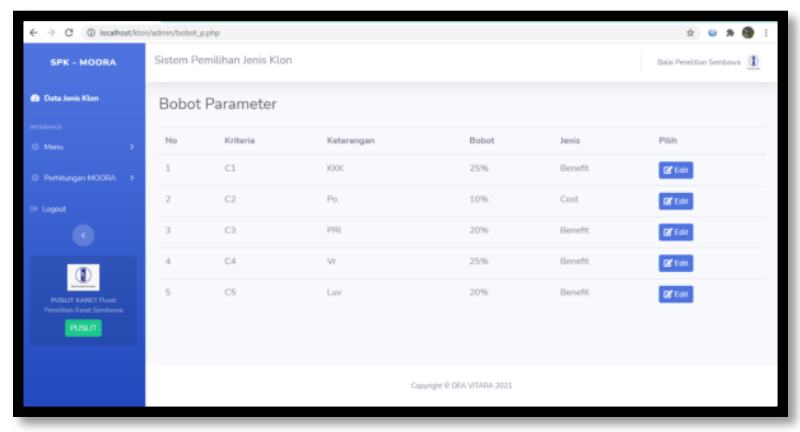

Gambar 8 Halaman Bobot Parameter

\subsubsection{Halaman Bobot Kriteria}

Pada halaman bobot kriteria untuk memberikan informasi, mengelolah data bobot Kriteria dan mengedit isi dari data. 


\section{Journal of Software Engineering Ampera}

Vol. 2, No. 1, February 2021 e-ISSN: xxxx-xxxx

https://journal-computing.org/index.php/journal-sea/index

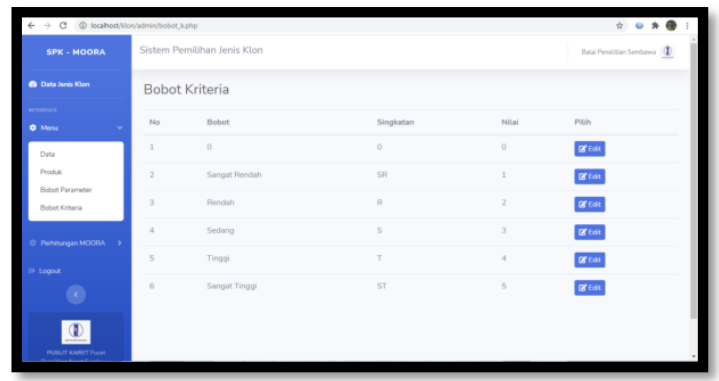

Gambar 9 Halaman Bobot Kriteria

\subsubsection{Halaman Matriks Keputusan}

Pada halaman matriks keputusan menampilkan tahap pertama dari metode perhitungan MOORA.

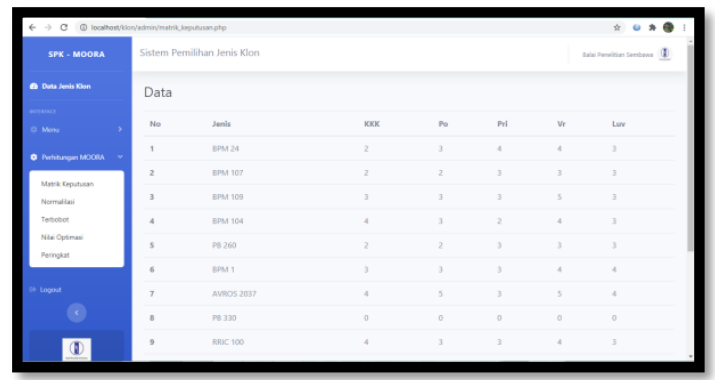

Gambar 10 Halaman Matriks Keputusan

\subsubsection{Halaman Normalisasi}

Pada halaman normalisasi menampilkan tahap kedua pada metode MOORA yaitu perhitungan pada normalisasi. Hasil normalisasi didapatkan dari perhitungan pada data.

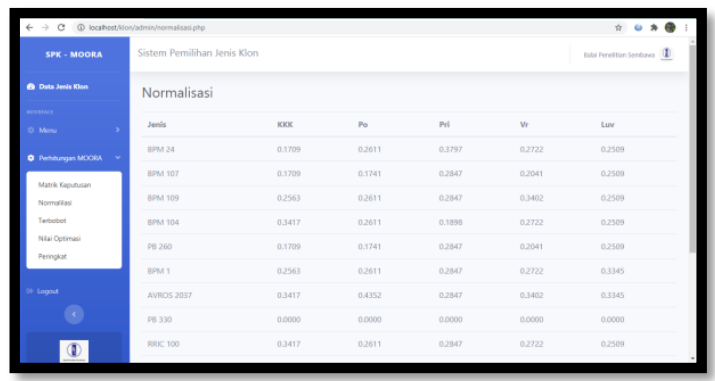

Gambar 11 Halaman Normalisasi 


\section{Journal of Software Engineering Ampera}

Vol. 2, No. 1, February 2021 e-ISSN: xxxx-xxxx

https://journal-computing.org/index.php/journal-sea/index

\subsubsection{Halaman Terbobot}

Pada halaman terbobot menampilkan tahap ketiga pada metode MOORA. Hasil terbobot didapatkan dari hasil normalisasi dikali dengan data pada bobot parameter.

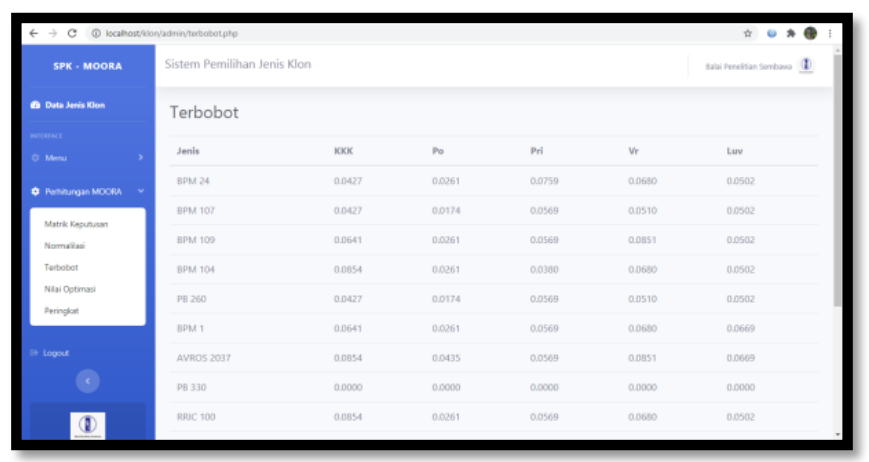

Gambar 12 Halaman Terbobot

\subsubsection{Halaman Nilai Optimasi}

Pada halaman ini menampilkan nilai optimasi tahap keempat pada perhitungan metode MOORA. Pada nilai optimasi ini sistem mengelola data benefit (max) dan cost (min).

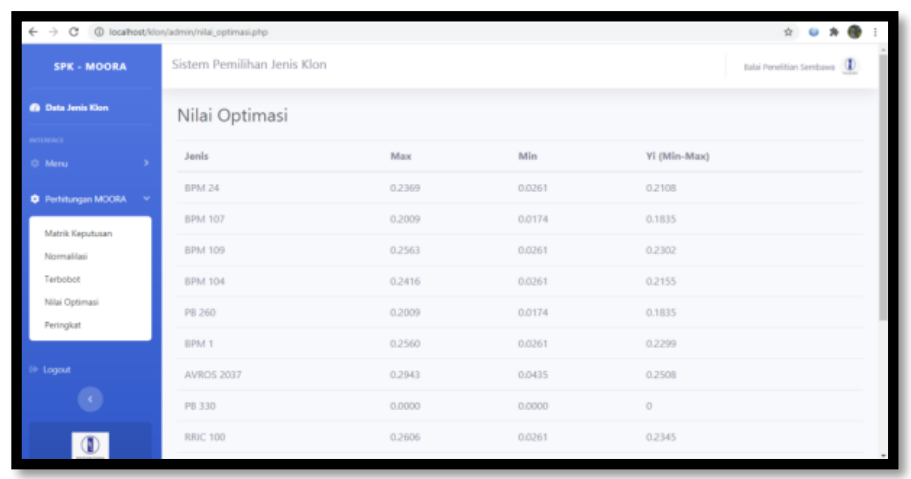

Gambar 13 Halaman Nilai Optimasi

\subsubsection{Halaman Peringkat}

Halaman peringkat menampilkan tahap kelima pada perhitungan metode MOORA. Menampilkan hasil peringkat untuk menentukan jenis klon terbaik. Hasil perhitungan pada nilai optimasi akan menetukan peringkat dari yang terbesar atau terbaik dari setiap jenis klon. 


\section{Journal of Software Engineering Ampera}

Vol. 2, No. 1, February 2021 e-ISSN: xxxx-xxxx

https://journal-computing.org/index.php/journal-sea/index

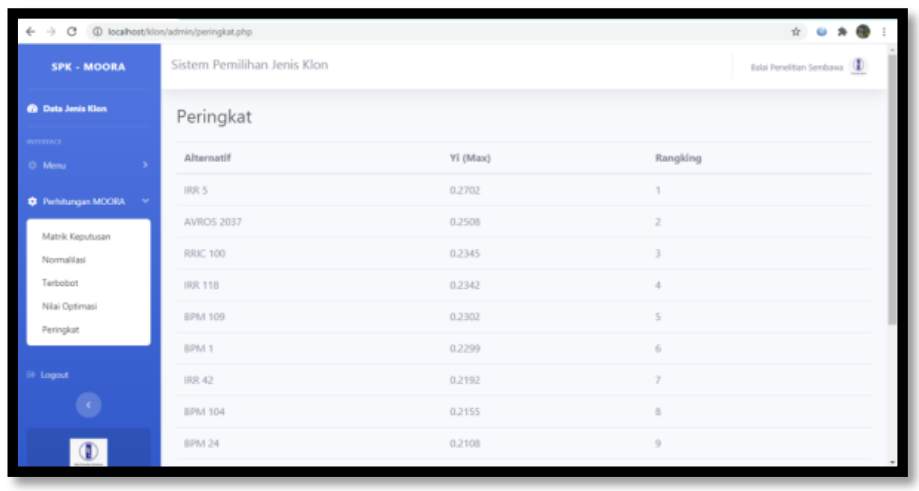

Gambar 14 Halaman Peringkat

\section{KESIMPULAN}

Sebagai kesimpulan dari penulisan skripsi ini adalah sebagai berikut.

1 Hasil penulisan pada skripsi ini adalah menghasilkan rancangan dan sebuat metode perhitungan untuk sistem berbasis web yang dibangun agar dapat menentukan jenis klon atau bibit tanaman karet yang terbaik yang digunakan pada Balai penelitian pusat penelitian tanaman karet Sembawa.

2 Dengan sistem ini dapat mempermudah menentukan bibit tanaman karet yang terbaik berdasarkan peringkat.

3 Pembuktian kebenaran sistem dibuktikan dengan melakukan perhitungan manual metode MOORA pada bab 3. Kemudian hasil yang diperoleh sistem memiliki kesamaan dengan perhitungan manual.

\section{DAFTAR PUSTAKA}

[1] Aswati, S., \& Siagian, Y. (2016). Model Rapid Application Developmentdalam Rancang Bangun Sistem Informasi Pemasaran Rumah (Studi Kasus: Perum Perumnas Cabang Medan)

[2] EFAN, S., Widya, C., \& Nia, O. (2020). Rancang Bangun Sistem Informasi Inventory Menggunakan Metode SDLC (System Development Life Cycle) Pada PT. Satria Jaya Prima (Doctoral dissertation, Universitas Bina Darma).

[3] Fadlan, C., Windarto, A. P., \& Damanik, I. S. (2019). Penerapan Metode MOORA pada Sistem Pemilihan Bibit Cabai (Kasus: Desa Bandar Siantar Kecamatan Gunung Malela). Journal of Applied Informatics and Computing, 3(2), 42-46. 


\section{Journal of Software Engineering Ampera}

Vol. 2, No. 1, February 2021 e-ISSN: xxxx-xxxx

https://journal-computing.org/index.php/journal-sea/index

[4] Hendini, A. (2016). Pemodelan UML sistem informasi monitoring penjualan dan stok barang (studi kasus: distro zhezha pontianak). Jurnal Khatulistiwa Informatika, 4(2).

[5] JATMIKA, A. (2017). Perancangan Sistem Informasi Portal Alumni Universitas Muhammadiyah Ponorogo Berbasis PHP dan MySQL (Doctoral dissertation, Universitas Muhammadiyah Ponorogo).

[6] Miranda, R., Hasibuan, N. A., Pristiwanto, P., \& Mesran, M. (2016). Sistem Pakar Mendiagnosa Penyakit Jamur Akar Putih (Riqidoporus Lignosus) Pada Tanaman Karet (Havea Brasiliensis) Dengan Metode Certainty Factor. JURIKOM (Jurnal Riset Komputer), 3(6).

[7] Revi, A., Parlina, I., \& Wardani, S. (2018). Analisis Perhitungan Metode MOORA dalam Pemilihan Supplier Bahan Bangunan di Toko Megah Gracindo Jaya. InfoTekJar: Jurnal Nasional Informatika dan Teknologi Jaringan, 3(1), 95-99.

[8] Ruliah, R. (2018). Model Certainty Factor Pada Sistem Pakar Untuk Mengidentifikasi Klon Karet Unggul. Jutisi: Jurnal IImiah Teknik Informatika dan Sistem Informasi, 6(3), 1623-1628.

[9] Sulistiani, H., \& Muludi, K. (2018). Penerapan metode certainty factor dalam mendeteksi penyakit tanaman karet.Jurnal Pendidikan Teknologi dan Kejuruan, 15(1).

[10] Suyanto, S., Cholil, W., \& Chandra, I. (2014). Penerapan metode ahp pada sistem penunjang keputusan kelayakan pemberian kredit. Semnasteknomedia online, 2(1), 2-04.

[11] Vachlepi, Afrizal dkk.2018.Saptabina Usahatani Karet Rakyat.Palembang :Balai Penelitian Sembawa-Pusat Penelitian Karet. 